\title{
Case Study: \\ A Comparative Analysis Of Financial And Quality Indicators Of Nursing Homes That Have Closed And Nursing Homes That Have Remained Open
}

Jim Morey, SUNY Institute of Technology, USA Ken Wallis, SUNY Institute of Technology, USA Hoseoup Lee, SUNY Institute of Technology, USA Gary Scherzer, SUNY Institute of Technology, USA Robert Orilio, SUNY Institute of Technology, USA

\begin{abstract}
Eight New York nursing homes, 4 open and 4 closed, were chosen at random for analysis. They were examined to determine if a relationship between age of assets, fiscal viability and quality of care existed. Three years of data for each nursing home was selected Several financial variables were used to construct a fiscal viability index; and a patient care index was created from selected measures that are used to measure specific aspects of institutional care. The premise was that the constructed indices will demonstrate a significant difference between closed nursing homes and homes remaining open. The analysis found that fiscal viability index could be a significant factor to differentiate the two groups of nursing homes, but the quality index showed no significant difference between the two groups.
\end{abstract}

\section{INTRODUCTION}

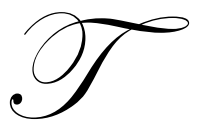

he purpose of this study was to examine if nursing homes that closed demonstrated deficiencies in quality, and if so, can declines in quality be preempted when closure due to poor financial status is found. In New York State $\$ 6,658,348,122$ was expended for skilled nursing facility care in 2007, or about $18 \%$ of total Medicaid expenditures. (NYSDOH, 2008) With declining State budgets, reductions in Medicaid funding are jeopardizing the fiscal viability of nursing homes.

\section{METHODOLOGY}

The methodology used age of assets, fiscal ratios and patient care data to create indexes in which correlations could be analyzed.

Various fiscal ratios, as outlined by Cleverly (Cleverly, 1997), were utilized to determine age of assets and to construct the fiscal viability index. These ratios are presented on Table 1.

The financial ratios were "combined" into a fiscal viability index utilizing the calculated ratios of the sample nursing homes. Specifically, the index was constructed using the following:

- $\quad$ Fiscal viability from Profitability: for each positive ratio, a score of .5 was assigned; and

- $\quad$ Fiscal viability from Capital Structure: for each positive ratio, a score of 1.0 was assigned. 
Thus, an overall fiscal viability rating for each hospital ranged from 0 (low) to 3 (high).

Table 1: Variables and ratios that determine age of asset and fiscal viability

\begin{tabular}{|l|l|l|}
\hline \multicolumn{1}{|c|}{ Variables } & \multicolumn{1}{c|}{ Ratio } & \multicolumn{1}{c|}{ Formula } \\
\hline Age of asset & Age of asset in years & Allowance for depreciation $\div$ annual depreciation expense \\
\hline \multirow{2}{*}{$\begin{array}{l}\text { Fiscal viability from } \\
\text { profitability }\end{array}$} & (1) Income margin & Net income $\div$ total operating revenue \\
\cline { 2 - 3 } $\begin{array}{l}\text { Fiscal viability from capital } \\
\text { structure }\end{array}$ & (2) Return on equity & Net income $\div$ unrestricted net asset \\
\cline { 2 - 3 } & (3) Equity financing & Unrestricted net asset $\div$ total asset \\
\hline
\end{tabular}

Source: Cleverly, W.O. 1997. Essentials of Health Care Finance, Fourth Edition. Aspen Publication.

The patient care measures employed were the Federal Medicare quality measures of the Centers for Medicare and Medicaid and used to assess the quality of care provided by nursing homes. (CMS, 2008). The data for the measure were gleaned from Minimum Data Sets Quality Indicators (MDS+), for this case study have been extracted from the MDS Repository. The MDS is collected on regular intervals for every resident in a Medicare or Medicaid certified nursing home. Information is collected on the resident's health, physical functioning, mental status, and general well-being. These data are used by the nursing home to assess needs and develop a plan of care unique to each resident.

Some MDS items used to calculate the quality measures consider the resident's condition during previous days prior to the assessment date. Table 2 provides these "observation" or "look back" time frames.

Table 2: Medicare quality indicators for nursing home patients and the New York State mean

\begin{tabular}{|l|c|c|}
\hline \multicolumn{1}{|c|}{ Quality Measures } & MDS Observation Time Frame & New York State mean \\
\hline $\begin{array}{l}\text { Percent of Residents Whose Need for Help With Daily } \\
\text { Activities Has Increased }\end{array}$ & Looks back 7 days & $12 \%$ \\
\hline Percent of Residents Who Have Moderate to Severe Pain & Looks back 7 days & $3 \%$ \\
\hline Percent of High-Risk Residents Who Have Pressure Sores & Looks back 7 days & $14 \%$ \\
\hline Percent of Low-Risk Residents Who Have Pressure Sores & Looks back 7 days & $3 \%$ \\
\hline Percent of Residents Who Were Physically Restrained & Looks back 7 days & $10 \%$ \\
\hline Percent of Residents Who are More Depressed or Anxious & Looks back 30 days & $52 \%$ \\
\hline $\begin{array}{l}\text { Percent of Low-Risk Residents Who Lose Control of Their } \\
\text { Bowels or Bladder }\end{array}$ & Looks back 14 days & $5 \%$ \\
\hline $\begin{array}{l}\text { Percent of Residents Who Have/Had a Catheter Inserted } \\
\text { and Left in Their Bladder }\end{array}$ & Looks back 14 days & $2 \%$ \\
\hline $\begin{array}{l}\text { Percent of Residents Who Spent Most of Their Time in } \\
\text { Bed or in a Chair }\end{array}$ & Looks back 7 days & $12 \%$ \\
\hline $\begin{array}{l}\text { Percent of Residents Whose Ability to Move About in and } \\
\text { Around Their Room Got Worse }\end{array}$ & Looks back 7 days & $7 \%$ \\
\hline Percent of Residents with a Urinary Tract Infection & Looks back 30 days & $9 \%$ \\
\hline Percent of Residents Who Lose Too Much Weight & Looks back 30 days & \\
\hline \begin{tabular}{l} 
Source: Cens \\
\hline
\end{tabular}
\end{tabular}

Source: Centers for Medicare and Medicaid Services

For each measure, data was presented that compared the nursing home with the New York State mean percentage rate. If the nursing home's rate was consistent with the State rate, the nursing home was considered to have a rate similar to the State's. If the rate was above or below the State's mean rate it was determined to be better or worse than the State's rate depending on the measure being assessed, respectively. 
Each nursing home was rated in comparison to the New York State rate. They scored 1 if they were consistent with the State mean, 0 if they were significantly worse, and 2 if better. These scores were then used to create an index score for the nursing homes in the sample.

Also reviewed was the number of survey deficiencies that each nursing home incurred on its most recent inspection. Nursing homes are inspected annually under the auspices of the Center for Medicare and Medicaid (CMS, 2008). Results from these surveys are provided under the heading of "deficiencies." While severity of deficiency was not measured in this examination, total number of deficiencies was utilized to glean frequency of negative survey findings.

Table 3: Three year mean quality indicator index scores*

\begin{tabular}{|c|c|c|c|c|c|c|c|c|c|c|}
\hline \multirow{2}{*}{$\begin{array}{l}\text { Quality } \\
\text { measure }\end{array}$} & \multicolumn{4}{|c|}{ Closed Nursing Homes } & \multirow{2}{*}{$\begin{array}{l}\text { Mean } \\
\text { scores }\end{array}$} & \multicolumn{4}{|c|}{ Open Nursing Homes } & \multirow{2}{*}{$\begin{array}{l}\text { Mean } \\
\text { scores }\end{array}$} \\
\hline & Nazareth & Childs & Episcopal & Menorah & & Bethany & Shepard & Mohawk & Harlem & \\
\hline $\begin{array}{l}\text { \% whose need } \\
\text { for help } \\
\text { w/ADLs has } \\
\text { increased }\end{array}$ & 1.7 & 0.5 & 0 & 0 & 1.5 & 0 & 0.7 & 0 & 0 & 2.0 \\
\hline $\begin{array}{l}\% \text { of } \\
\text { w/moderate to } \\
\text { severe pain }\end{array}$ & 1.7 & 0.5 & 0 & 1.3 & 1.7 & 0 & 0 & 2.0 & 2.0 & 2.0 \\
\hline $\begin{array}{l}\% \text { of high-risk } \\
\text { residents } \\
\text { w/pressure } \\
\text { sores }\end{array}$ & 1.0 & 0 & 0.7 & 0 & 1.7 & 1.7 & 1.3 & 1.3 & 0.7 & 1.9 \\
\hline $\begin{array}{l}\% \text { of low risk } \\
\text { residents } \\
\text { w/pressure } \\
\text { sores }\end{array}$ & 0.7 & 0 & 1.7 & 1.3 & 1.8 & 2.0 & 2.0 & 2.0 & 1.3 & 2.0 \\
\hline $\begin{array}{l}\% \text { physically } \\
\text { restrained }\end{array}$ & 1.3 & 0 & 1.3 & 1.7 & 1.6 & 1.0 & 2.0 & 0 & 2.0 & 2.5 \\
\hline $\begin{array}{l}\% \text { more } \\
\text { depressed or } \\
\text { anxious }\end{array}$ & 1.3 & 1.0 & 0 & 2.0 & 2.0 & 0.7 & 0 & 0.7 & 1.7 & 1.8 \\
\hline $\begin{array}{l}\% \text { of low-risk } \\
\text { residents who } \\
\text { lose control of } \\
\text { bowels or } \\
\text { bladder }\end{array}$ & 1.3 & 2.0 & 0.7 & 2.0 & 1.8 & 0 & 0.7 & 1.0 & 0.7 & 1.4 \\
\hline $\begin{array}{l}\% \text { who had a } \\
\text { catheter } \\
\text { inserted and } \\
\text { not removed }\end{array}$ & 1.7 & 2.0 & 0 & 1.7 & 1.8 & 0.3 & 0.3 & 0 & 2.0 & 1.6 \\
\hline $\begin{array}{l}\text { \% who spent } \\
\text { most of their } \\
\text { time in bed or } \\
\text { chair }\end{array}$ & 2.0 & 0.0 & 0 & 0 & 2.0 & 1.7 & 0.3 & 2.0 & 2.0 & 1.8 \\
\hline $\begin{array}{l}\% \text { w/declining } \\
\text { ambulation }\end{array}$ & 1.3 & 0.5 & 1.0 & 0.7 & 1.7 & 2.0 & 2.0 & 2.0 & 1.3 & 2.0 \\
\hline $\begin{array}{l}\% \text { w/urinary } \\
\text { tract infection }\end{array}$ & 1.0 & 0 & 2.0 & 2.0 & 1.9 & 0.3 & 1.3 & 0 & 2.0 & 1.8 \\
\hline $\begin{array}{l}\% \text { who lose } \\
\text { too much } \\
\text { weight }\end{array}$ & 2.0 & 0 & 0.7 & 1.0 & 1.8 & 0.7 & 1.3 & 2.0 & 0.3 & 1.9 \\
\hline
\end{tabular}

Source: New York State Department of Health, 2008

*The 3 year mean score for the respective homes may not be from the same 3 year period due to availability of data; and in some cases no score has been recorded. 


\section{DATA ANALYSIS}

Table 4: Descriptive Statistics of Nursing Home Sample by Failure Status (information over a 3-year period on 4 nursing homes for each status)

\begin{tabular}{|c|c|c|c|c||c|c|c|c|}
\hline \multirow{2}{*}{ Variable } & \multicolumn{9}{|c|}{ Nursing Home Status } \\
\cline { 2 - 8 } & $\mathbf{N}$ & Mean & $\begin{array}{c}\text { Standard } \\
\text { deviation }\end{array}$ & Median & $\mathbf{N}$ & Mean & $\begin{array}{c}\text { Standard } \\
\text { deviation }\end{array}$ & Median \\
\cline { 2 - 8 } & 12 & 13.72 & 6.154 & 15.288 & 12 & 19.643 & 6.623 & 21.63 \\
\hline Age of Asset & 12 & 0.583 & 0.793 & 0 & 12 & 1.917 & 0.9 & 2 \\
\hline $\begin{array}{c}\text { Fiscal Viability } \\
\text { (FV) }\end{array}$ & 12 & $-10.96 \%$ & $4.08 \%$ & $-11.34 \%$ & 12 & $-1.86 \%$ & $6.95 \%$ & $-1.97 \%$ \\
\hline $\begin{array}{c}\text { FV } \\
\text { (Net income margin) }\end{array}$ & 12 & $-1,861$ & 1,578 & $-1,219$ & 12 & -223 & 629 & -171 \\
\hline $\begin{array}{c}\text { FV } \\
\text { (Return on equity) } *\end{array}$ & 12 & $-13.62 \%$ & $30.87 \%$ & $-5.2 \%$ & 12 & $30.78 \%$ & $14.34 \%$ & $32.94 \%$ \\
\hline $\begin{array}{c}\text { FV } \\
\text { (Capital structure) }\end{array}$ & 12 & $-8.29 \%$ & $8.43 \%$ & $-6.91 \%$ & 12 & $4.97 \%$ & $14.48 \%$ & $2.11 \%$ \\
\hline $\begin{array}{c}\text { FV } \\
\text { (CF over debt) }\end{array}$ & 11 & 0.977 & 0.393 & 1.083 & 12 & 1.069 & 0.321 & 1.08 \\
\hline Quality Score & 11 & 12.727 & 7.44 & 11 & 12 & 19.33 & 11.85 & 18 \\
\hline Deficiency
\end{tabular}

* With negative equity positions in failed nursing homes, net income is used for return on equity, instead.

Table 4 presents the descriptive statistics for nursing home data in two groups: ones that closed and ones that stay open. Open nursing homes appear to keep older assets (building, equipment, and facilities) than closed nursing homes. In addition, open nursing homes on the average show higher fiscal viability index with respect to all fiscal factors in net income margin, return on equity, capital structure, and cash flow to debt ratios. With the nonprofit status of nursing homes in our study, they show negative profitability ratios (net income margin and return on equity). As to the quality index, average scores of patient care quality measures for both closed and open nursing-home groups do not appear different $(0.977$ and 1.069 for mean and 1.083 and 1.08 for median, respectively). For the number of deficiency reports that each nursing home received, open nursing homes on the average received greater number of report.

In addition to descriptive statistics of both closed and open nursing homes, Cochran's t-tests are applied to identify the differences between closed and open nursing homes with factors like age of assets, fiscal viability, patient care quality, and the number of deficiency reports. Contrary to regular t-tests, Cochran's t-test does not assume the identical variances in two (closed and open nursing home) groups. With a limited number of nursing homes in our analysis, we cannot claim that two groups should show the same variance.

Also in our analysis is to examine the differences in changes in factors (age, fiscal viability, quality measure, deficiency) between two groups. For example, certain nursing homes may experience deteriorating fiscal or quality conditions that may lead to the ultimate closure of those nursing homes. We calculated the changes in those factors in one year from previous year, and examined whether there is significant difference in the changes between closed and open nursing homes.

Finally, we performed the correlation analysis between various factors (age, fiscal viability, quality measures and deficiency) to find whether there is any significant relationship among those factors. Also examined is whether there is any difference in the correlation of factors between closed and open nursing homes. 


\section{FINDINGS}

As presented in Table 5, we found a significant difference (1.33) in fiscal viability between closed and open nursing homes, but not in age of asset and quality variables $(-5.92,0.092$ and 6.61 for age, quality score and deficiency, respectively). Especially, all fiscal-viability factors we examined (net income margin, return on equity, capital structure, cash flow to debt ratios) are significant at least 5\% level, and their directions of differences are as expected (i.e. closed nursing homes tend to show worse fiscal viability factors). From the results, it appears that nursing homes failed because of their bad financial conditions, rather than their quality of service.

Table 5: Differences in Fiscal viability and quality between Closed and Opened Nursing homes (Cochran t- test for unequal variances)

\begin{tabular}{|c|c|c|c|c|c|c|}
\hline \multirow{3}{*}{ Variable } & \multirow{2}{*}{\multicolumn{2}{|c|}{$\begin{array}{c}\text { Mean } \\
\text { Nursing Home status } \\
\end{array}$}} & \multirow{3}{*}{$\begin{array}{l}\text { Difference } \\
\text { in means }\end{array}$} & \multirow{3}{*}{$\begin{array}{l}\text { Expected } \\
\text { direction }\end{array}$} & \multirow{3}{*}{$\begin{array}{c}\text { t-value } \\
\text { (significance level) }\end{array}$} & \multirow{3}{*}{$\begin{array}{c}\text { F-value } \\
\text { (significance level) }\end{array}$} \\
\hline & & & & & & \\
\hline & Closed & Open & & & & \\
\hline Age of Asset & 13.72 & 19.643 & -5.92 & + & $-2.27(* *)$ & 1.16 \\
\hline Fiscal Viability (FV) & 0.583 & 1.917 & -1.33 & - & $-3.85(* * *)$ & 1.29 \\
\hline FV (Net income margin) & $-10.96 \%$ & $-1.86 \%$ & $-9.1 \%$ & - & $-3.9(* * *)$ & $2.91(*)$ \\
\hline FV (Return on equity) * & $-1,861$ & -223 & $-1,638$ & - & $-3.34(* * *)$ & $6.29(* * *)$ \\
\hline FV (Capital structure) & $-13.62 \%$ & $30.78 \%$ & $-44.4 \%$ & - & $-4.52(* * *)$ & $4.63(* *)$ \\
\hline FV (CF over debt) & $-8.29 \%$ & $4.97 \%$ & $-13.3 \%$ & - & $-2.74(* *)$ & $2.95(*)$ \\
\hline Quality Score & 0.977 & 1.069 & -0.092 & - & -0.61 & 1.49 \\
\hline Deficiency & 12.727 & 19.33 & -6.61 & + & -1.61 & 2.53 \\
\hline
\end{tabular}

* With negative equity positions in failed nursing homes, net income is used for return on equity, instead.

(significance level) *** significant at $1 \%$ level; ** significant at $5 \%$ level; * significant at $10 \%$ level.

As presented in Table 6, we also examined whether there are significant differences in changes in financial conditions or quality of services between closed and open nursing homes. For example, the deteriorating financial conditions or quality of service may drive nursing homes to failure. We determined year-to-year changes in the fiscal-viability, age of asset, and quality, and applied them to the same statistical tests.

We found that except for the change in capital structure, there are no significant differences in changes in factors we examined. In other words, financial difficulties in closed nursing homes have existed at least three years before they finally failed. Probably, non-profit status of the nursing homes in our study may play an important role in no significant changes in factors over a three-year period, as we find a large amount of negative net equity (unrestricted fund balance) position in our closed nursing home samples.

Table 6: Differences in Changes in Fiscal viability and quality between Closed and Opened Nursing homes (Cochran t- test for unequal variances)

\begin{tabular}{|c|c|c|c|c|c|c|}
\hline \multirow{3}{*}{ Variable } & \multirow{2}{*}{\multicolumn{2}{|c|}{$\begin{array}{c}\text { Mean } \\
\text { Nursing Home status } \\
\end{array}$}} & \multirow{3}{*}{$\begin{array}{l}\text { Difference } \\
\text { in means }\end{array}$} & \multirow{3}{*}{$\begin{array}{l}\text { Expected } \\
\text { direction }\end{array}$} & \multirow{3}{*}{$\begin{array}{c}\text { t-value } \\
\text { (significance level) }\end{array}$} & \multirow{3}{*}{$\begin{array}{c}\text { F-value } \\
\text { (significance level) }\end{array}$} \\
\hline & & & & & & \\
\hline & Closed & Opened & & & & \\
\hline Age of Asset & 0.09 & 2.12 & -2.03 & + & -1.92 & 2.18 \\
\hline Fiscal Viability (FV) & -0.125 & 0.125 & -0.25 & - & -0.6 & 2.39 \\
\hline FV (Net income margin) & $-1.8 \%$ & $3 \%$ & $-4.8 \%$ & - & -1.4 & 2.71 \\
\hline FV (Return on equity) $*$ & -443 & -174 & -617 & - & -0.81 & $8.33(* * *)$ \\
\hline FV (Capital structure) & $-22.06 \%$ & $-0.74 \%$ & $-21.3 \%$ & - & $-3.77(* * *)$ & 3.26 \\
\hline FV (CF over debt) & $-2.45 \%$ & $3.87 \%$ & $-6.3 \%$ & - & -1.14 & 1.11 \\
\hline Quality Score & 0.012 & 0.114 & -0.103 & - & -0.52 & 3.27 \\
\hline Deficiency & -3 & -0.25 & -2.75 & + & 0.81 & $5.28(*)$ \\
\hline
\end{tabular}

(significance level) *** significant at $1 \%$ level; ** significant at $5 \%$ level; * significant at $10 \%$ level. 
Finally, we performed the correlation analysis on our nursing home samples, as shown in Table 7. With all nursing homes examined, nursing homes with higher quality measure show a lower number of deficiencies (-0.358), but this result is marginally significant. When we apply the same analysis on the closed nursing homes, the negative relationship between quality measure and deficiencies becomes almost doubled (-0.652) and statistically significant at 5\% level. This result indicates that it is quite more apparent for closed nursing homes as they struggle in both quality of services they provide to their customers and number of deficiencies received.

As to the relationship between the age of assets and quality indicator, the negative impact of older facilities and equipments is much greater for closed nursing homes (-0.625) than open nursing homes $(0.49)$.

The relationship between the age of assets and survey deficiencies is rather contrasted further, depending on the status of nursing homes. For closed nursing homes, older facilities tend to bring in the greater number of deficiencies reported (0.699) against the nursing homes. On the contrary, for open nursing homes the relationship is negative (-0.768), which indicates that nursing homes with older facilities received smaller number of deficiency reports.

The relationships of financial viability with survey deficiencies and the age of assets become as expected (0.448 and -0.689 ) and are significant with closed nursing home

Table 7: Correlation analysis for fiscal viability, age of assets, quality indicator, and survey deficiencies between closed and open nursing homes

\begin{tabular}{|l|c|c|c|c|}
\hline \multirow{2}{*}{ Variables } & \multirow{2}{*}{$\begin{array}{c}\text { Expected } \\
\text { direction }\end{array}$} & $\begin{array}{c}\text { All } \\
\text { Nursing homes }\end{array}$ & $\begin{array}{c}\text { Correlation Coefficient (significance level) } \\
\text { homes }\end{array}$ & $\begin{array}{c}\text { Open } \\
\text { Nursing homes }\end{array}$ \\
\cline { 3 - 5 } & - & $-0.358(*)$ & $-0.652(* *)$ & -0.313 \\
\hline $\begin{array}{c}\text { Quality indicator \& } \\
\text { Survey deficiencies }\end{array}$ & - & -0.018 & $-0.625(* *)$ & 0.49 \\
\hline $\begin{array}{c}\text { Age of assets \& } \\
\text { Quality indicator }\end{array}$ & + & -0.059 & $0.699(* *)$ & $-0.768(* * *)$ \\
\hline $\begin{array}{c}\text { Age of assets \& } \\
\text { Survey deficiencies }\end{array}$ & + & -0.028 & 0.068 & -0.371 \\
\hline $\begin{array}{c}\text { Financial viability \& } \\
\text { Quality indicator }\end{array}$ & - & 0.172 & $-0.448(*)$ & 0.156 \\
\hline $\begin{array}{c}\text { Financial viability \& } \\
\text { Survey deficiencies }\end{array}$ & - & 0.005 & $-0.689(* *)$ & -0.146 \\
\hline $\begin{array}{c}\text { Age of assets \& } \\
\text { Financial viability }\end{array}$ & & \\
\hline
\end{tabular}

(significance level) *** significant at $1 \%$ level; ** significant at 5\% level; * significant at $10 \%$ level.

With all nursing homes examined, nursing homes with a higher quality measure show a lower number of deficiencies, but this result is marginally significant. With closed nursing homes, the negative relationship between quality measure and deficiencies becomes almost doubles and statistically significant at 5\% level. This result indicates that it is quite more apparent for closed nursing homes that they struggle in both quality of services they provide to their customers and number of deficiencies received.

As to the relationship between the age of assets and quality indicator, the negative impact of older facilities and equipments is much greater for closed nursing homes.

The relationship between the age of assets and survey deficiencies is rather contrasted further, depending on the status of nursing homes. For closed nursing homes, older facilities tend to bring in more deficiencies reported against the nursing homes. On the contrary, for open nursing homes the relationship is negative. 
The relationships of financial viability with survey deficiencies and the age of assets become as expected and significant with closed nursing home

\section{CONCLUSIONS}

Four cases of closed nursing homes were compared with four open ones to identify factors that may explain the nursing home failures. Especially, we examined various financial (age of assets, fiscal viability) as well as nursing home quality measures as potential differentiating factors for the failures.

The key findings of this research are:

- $\quad$ Closed nursing homes experience significantly worse financial conditions (fiscal viability with respect to net income margin, return on equity, capital structure, and CF) than open nursing homes.

- There is no significant difference between closed and open nursing home in nursing home quality measures.

- $\quad$ Except for capital structure, there is no significant year-to-year change between closed and open nursing homes. This means that fiscal difficulties or deteriorating quality of closed nursing homes existed long before the failures.

- $\quad$ For closed nursing homes, there were significant relationships between (1) quality of nursing home care and number of deficiencies, (2) age of assets and quality of nursing home care, (3) financial viability and number of deficiencies, and (4) age of assets and fiscal viability.

- $\quad$ For open nursing homes, there was no significant relationship between variables.

In conclusion, the fiscal difficulties in nursing homes are bigger contributor of nursing home failures. Closed nursing homes show more significant interactions of fiscal and quality factors than open nursing homes.

\section{REFERENCES}

1. Centers for Medicare and Medicaid Services (CMS), Department of Health and Human Services, 2008.

2. Cleverly, W.O. 1997. Essentials of Health Care Finance, Fourth Edition. Aspen Publication.

3. "IRS Form 990" for years 2002 - 2005; www.Guidestar.org

4. Medicaid Quarterly Reports of Beneficiaries, Expenditures, and Units of Service by Category of Service by Aid Category by Region, New York State Department of Health, 2008. 
NOTES 